that scenes from them have been recorded for various dialect surveys. Many of us, whether chemists or not, will recall his discovery of a group of epigrams written in Latin elegiac couplets embodying alchemical doctrines and set to music by Count Maier, alchemist to Rudolf II. These set in modern musical notation by F. W. Sawyer were sung by a choir from St. Andrews University at the Royal Institution by invitation of Sir William Bragg.

It is not altogether surprising therefore to learn that the first British recipient of the American Chemical Society's Dexter Award for distinguished contributions to the history of chemistry was John Read, who received it in 1959. The citation for the award aptly' sums up much of his achievement in that it commemorates "the meritorious services over a long period of time" of "one of the most versatile of Scientists as well known for his literary accomplish. ment as for his researches in organic chemistry".

In 1916 Prof. Read married Ida Suddards, who survives him with one of their two sons, the other son having lost his life tragically in a mountaineering accident just over a year ago.

E. L. HiRsT

\section{Prof. G. A. Clark, C.B.}

GEORGE Clark, who died on February 9, was professor of physiology and dean of the Faculty of Medicine in the University of Sheffield from 1933 until 1946, when he left to join the staff of the Ministry of Health.

He graduated at the University of Durham during the First World War, and his studies were interrupted by two years' service as surgeon-probationer in the Royal Naval Volunteer Reserve. He was released from service to complete his degree course and graduated with honours in 1917. He then rejoined the Royal Navy for two years as surgeon- lieutenant. He never lost his love for the Senior Service and after the First World War he served with the Royal Naval Volunteer Reserve for many years.

In 1919 Clark was appointed lecturer in physiology in the University of Durham, where he remained until 1924. He then joined the Department of Physiology in Sheffield under the late Prof. J. B. Leathes, for whom he had the greatest admiration and affection. When Leathes retired in 1933, Clark succeeded him to the chair. Leathes had given much thought to the revision of the medical curriculum, with the view of attaining a much eloser relationship between the pre-clinical and clinical subjects. Therein he was enthusiastically supported by George Clark, whose talents for organization were soon recognized. As a result he was elected dean of the Faculty of Medicine soon after his appointment to the chair of physiology, and he served as dean until he left in 1946.

Clark had a very clear and penetrating mind, and initiated a number of schemes for the better welfare and teaching of students. The clinical professorial chairs were held on a part-time basis, and teaching was often subservient to the demands of private practice, and relations between the clinical departments and the University were often tənuous. In order to provide better organized teaching, Clark pressed for the establishment of full-time chairs in the major elinical subjects. He also supported the plan for building a University Teaching Hospital, a single building providing complete facilities for undergraduates, and replacing the four separate hospitals where clinical teaching is still provided. At the time, these revolutionary ideas aroused anger and opposition among some clinicians and led to quarrels. Nevertheless, it is now recognized that Clark's ideas were right and a number of full-time chairs have been created, and their advantage in organizing teaching and advancing research is apparent.

Clark was also instrumental in setting up a University Student Health Service, which provides medical care for undergraduates and has served as a model for other universities. He also played a large part in the formation of the School of Nursing.
During his time in Sheffield, George Clark served on $a_{0}$ great many committees, including the General Medical Council, and took an active part in them all. So much was he preoccupied that he had less and less time to devote to physiology. In 1946 he resigned and joined the Ministry of Health as a principal medical officer. There his experience and capabilities were available for the integration of medical education with the Health Service. He continued to serve on the General Medical Council and completed twenty-four year's in 1962. His loyal services were recognized by the C.B. in 1954 .

George Clark made firm and lasting friendships, which he greatly valued. Although he visited Sheffield only rarely after he left, he kept in touch with many of us, and his friends were always welcome to call on him at the Ministry.

George will long be remembered by his many friends, and his former students will remember him with gratitude and pleasure.

J. WILKIE

\section{Dr. S. E. Jacobs}

Dr. Stanley E. JacoBs died on January 27, following a short stay in hospital necessitated by a chest infection. Although he had not been particularly robust in health for a number of years, it is certain that the extremely bad London smog in December did not help his condition. He will probably be best remembered as editor of the Journal of Applied Bacteriology.

Stanley Jacobs was born in London on June 23, 1905. Before he entered the Imperial College of Science and Technology in $\mathbf{1 9 2 3}$ he attended the Strand School, London. In 1925 he obtained his associateship of the Royal College of Science in chemistry, being first in the diploma list. He was also awarded the Frank Hatton Prize for proficiency in advanced chemistry. In 1926 he gained a B.Sc. degree with honours in chemistry. Three years later he was awarded a Ph.D. in bacteriology by the University of London. Prior to that time, he was appointed as a demonstrator in bacteriology for Dr. Paine in the Department of Biology under the direction of Prof. Farmer. This position he retained until 1933, when he was appointed assistant lecturer in the Department of Bacteriology under the direction of Prof. V. H. Blackman. Thereafter he was successively lecturer in the Department of Botany in 1938, senior lecturer in the Department of Botany and Plant Physiology in 1946, and in 1950 was appointed reader in bacteriology in the University of London and assistant professor of bacteriology of the Imperial College, positions which he held until his death.

The contributions Stanley Jacobs made in the world of microbiology in original research and teaching have been outstanding. In spite of recurrent poor health, he engaged in a number of outside activities. He lectured for some years in bacteriology at the Sir John Cass Technical Institution in London and also for a short time at the Chelsea Polytechnic. $\mathrm{H}_{\theta}$ was for a number of years chairman of the Special Advisory Board in Microbiology in the University of London and was a member of the Panel on Co-ordination of Research Contracts on selected topics in radiobiology under the auspices of the International Atomic Energy Agency, and he contributed to the Vienna meetings of this body in 1960 and 1961. He was consultant to the Rubber Research Institute of Malaya, and it was on a trip to Kuala Lumpur by air in 1961 that he was taken seriously ill with a spontaneous pneumothorax leading to serious damage to the lung which undoubtedly weakened his resistance against the polluted London atmosphere. He was a prime mover in initiating a postgraduate M.Sc. course in microbiology at the Imperial College. This course was much in demand and it is hoped it will not die along with its originator.

In the field of original research, Stanley Jacobs was interested in a wide variety of subjects, as was to be 